AGH DRILLING, OIL, GAS • Vol. $31 \cdot$ No. $2 \cdot 2014$

http://dx.doi.org/10.7494/drill.2014.31.2.341

\author{
Tomasz Wlodek*, Szymon Kuczyński*, Jacek Hendel*
}

\title{
TECHNICALAND ECONOMIC ISSUES OF OFFSHORE PIPELINE CARBON DIOXIDE TRANSPORTATION
}

\section{INTRODUCTION}

$\mathrm{CO}_{2}$ pipeline transportation is one of method to transfer captured $\mathrm{CO}_{2}$ from power plant to storage sites for geological sequestration or for enhanced hydrocarbon recovery at short or medium distance from capture plant location. In this paper the basic conditions of offshore carbon dioxide transportation are presented. Various flow conditions as well as the process of choosing of technological installations concept for efficient carbon dioxide pipeline transport are assumed in this paper. The flexible coiled-tubing pipeline was considered for capital investment costs reduction. Due to the limited availability of coiled-tubing pipes over 5" in diameter, for the transport of larger quantities of $\mathrm{CO}_{2}$ it is required to use classical pipeline consisting of welded pipes. The pipeline is planned to be disposed on the seabed. It would be placed from a $\mathrm{CO}_{2}$ preparation and pumping station on land to the offshore platform in the geological storage site area. In the area of a geologic structure the pipeline is linked to the platform installation above the sea level, and from that point carbon dioxide is pumped down to the reservoir structure. Also the costs of offshore pipeline transport are presented in this paper in comparison to onshore pipeline transport and ship transport costs.

\section{COSTS OF $\mathrm{CO}_{2}$ TRANSPORTATION}

Based on worldwide experiences widely presented in journals, reports, and on workshops, it could be defined three different possibilities of $\mathrm{CO} 2$ transportation:

- by onshore pipeline;

- by offshore pipleline;

- by ships

* AGH University of Science and Technology, Faculty of Drilling, Oil and Gas, Krakow, Poland 
Figure 1. presents costs of $\mathrm{CO}_{2}$ transportation by tree methods listed above as a function of distans from $\mathrm{CO}_{2}$ source to destination point. Costs include: storage facilities (intermediate ,if needed), marine fees, fuel and loading/unloading costs.

In general, according to IPCC [1], costs of $\mathrm{CO}_{2}$ transportation could be summarized into three categories. Various components of total costs $\mathrm{CO}_{2}$ transportation by pipeline are presented in table 1. The examples of various costs might be found in Zero Emmision Platform Reports [2].

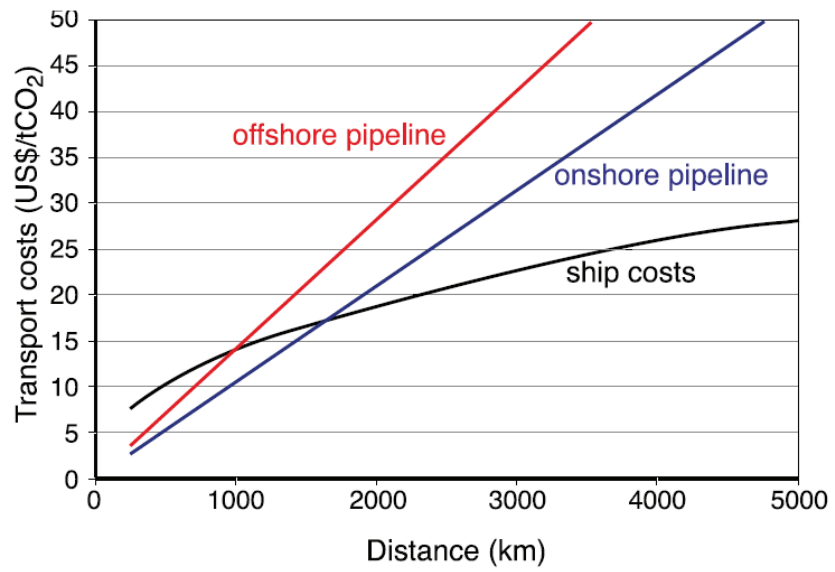

Fig. 1. $\mathrm{CO}_{2}$ transport costs vs. distance for different transportation methods [1]

Table 1

$\mathrm{CO}_{2}$ transportation costs [1]

\begin{tabular}{|c|c|c|}
\hline Construction costs including: & $\begin{array}{c}\text { Pipeline mentaince and } \\
\text { operation costs including: }\end{array}$ & Other costs including: \\
\hline - $\begin{array}{c}\text { material \& equipment cost; - } \\
\text { pipe (steel price, coating e.g. }\end{array}$ & $-\begin{array}{l}\text { monitoring \& maintenance; } \\
\text { 3 mm polypropylene) } \\
\text { energy usage }\end{array}$ & - pipeline project; \\
$-\begin{array}{l}\text {-anti-corrosion protection } \\
\text { systems (cathodic); }\end{array}$ & & - project managment; \\
$-\begin{array}{l}\text { telecomunication and signal } \\
\text { processing equipment; } \\
\text { booster station (compres- } \\
\text { sors), if needed } \\
\text { pipeline building and equip- } \\
\text { ment installiation expendi- } \\
\text { ture (labour costs) }\end{array}$ & & $-\begin{array}{l}\text { regulatory filing fees } \\
\text { other market factors }\end{array}$ \\
\hline
\end{tabular}


Costs of materials and equipment used in $\mathrm{CO}_{2}$ transportation are a function of four main parameters listed below (IPCC, 2005):

- $\mathrm{CO}_{2}$ flow rate in pipeline;

- pipeline diameter;

- pipelie length;

- quality of transported $\mathrm{CO}_{2}$ (pressure and moisure content)

Figure 2 shows example of transportation costs as a function of $\mathrm{CO}_{2}$ flow rate for onshore (red lines) and offshore (blue lines) pipelines on $250 \mathrm{~km}$ distance. High costs for onshore and offshore pipelines (dashed lines) and low costs for both (continuous lines) are presented [1].

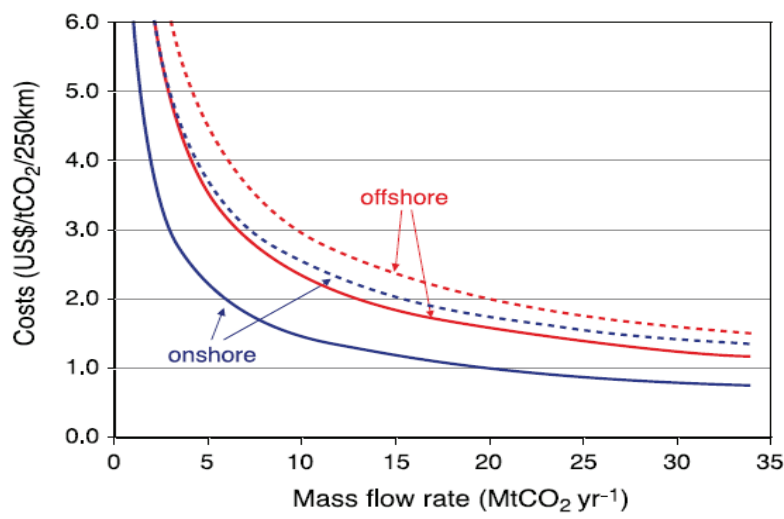

Fig. 2. Transportation costs vs. $\mathrm{CO}_{2}$ mass flow rate [1]

Based on reports prepared by Zero Emmision Platform [2] and Welkenhuysen and Compernolle work [3], $\mathrm{CO}_{2}$ transportation costs as a function of offshore pipelines length was calculated and shown on figure 3 .

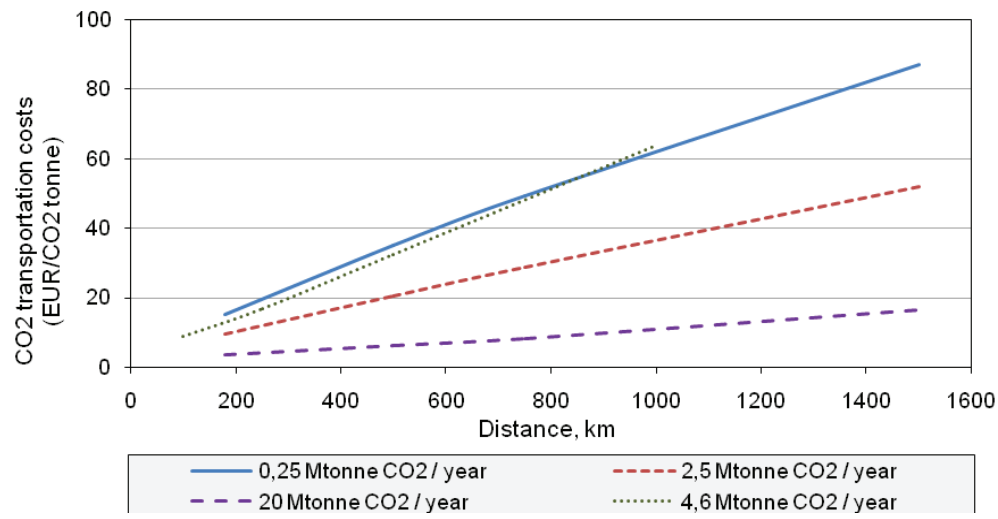

Fig. 3. $\mathrm{CO}_{2}$ transportation costs vs. offshore pipelines length, based on: $[2,3]$ 
Total investment costs for onshore and offshore pipelines are shown on figure 4. For calculation capital charge rate of $15 \%$ was taken and $100 \%$ for load factor. Costs of $\mathrm{CO}_{2}$ transportation as a function of diameter are presented on figure 5. For both cases capital expenditures do not include booster station.

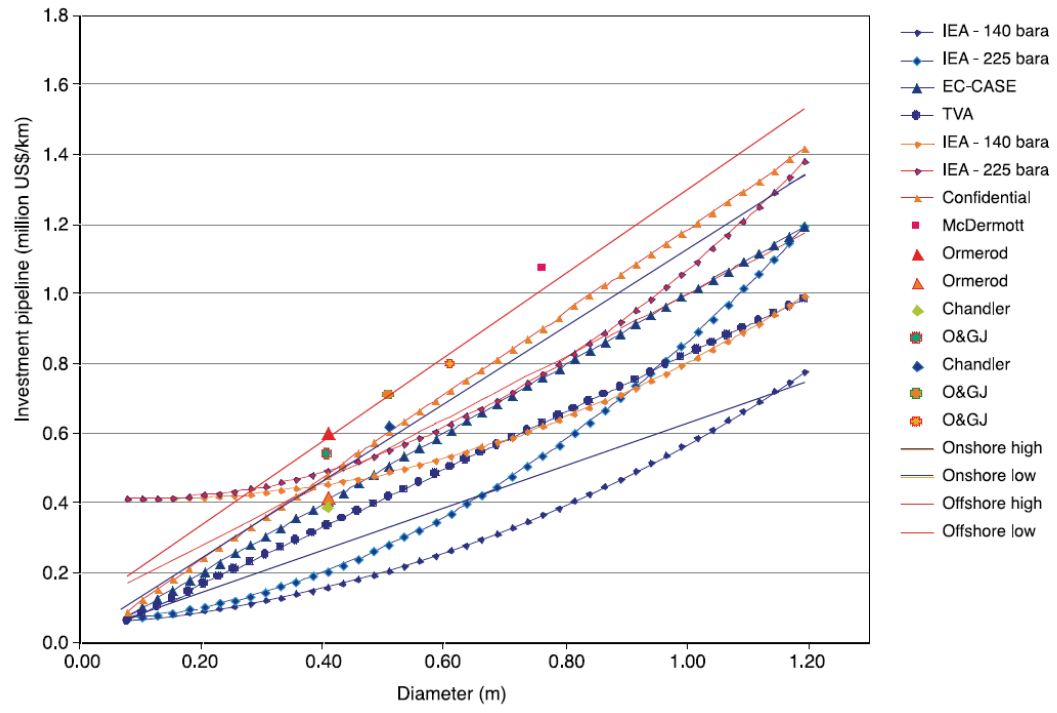

Fig. 4. Total investment costs for onshore and offshore pipelines without booster station costs $[1,4,5,6,7,8,9,10,11,12]$

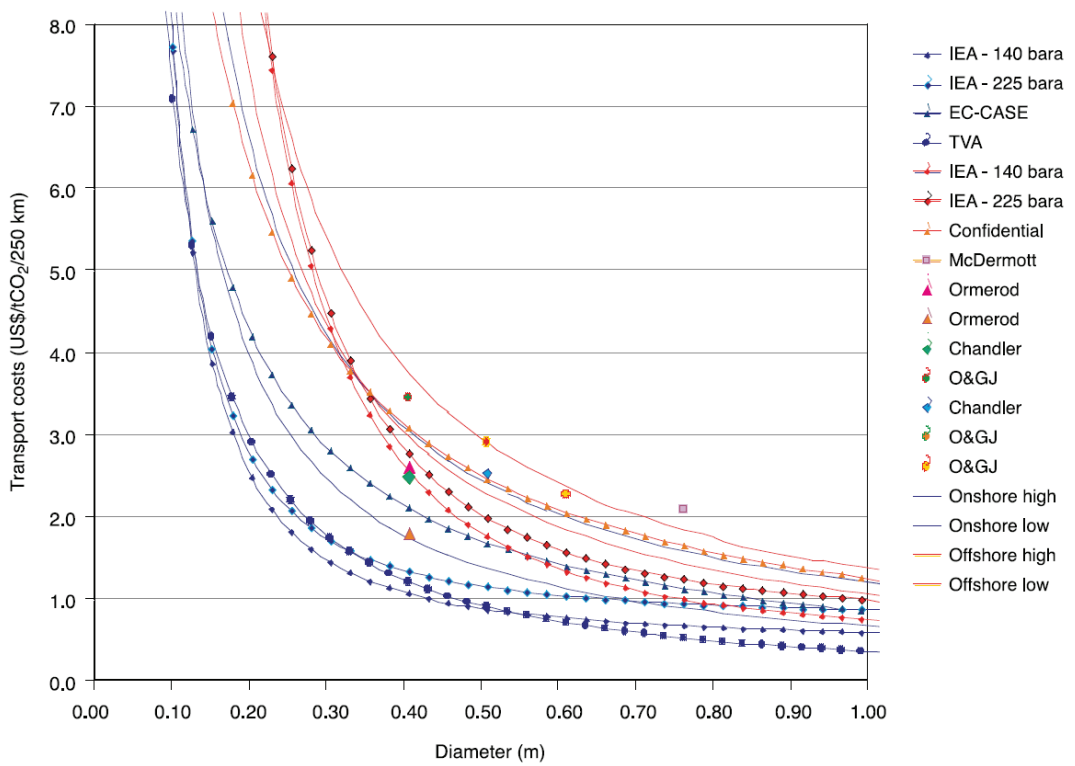

Fig. 5. Transport costs for onshore and offshore pipeline $[1,4,5,6,7,8,9,10,11,12]$ 


\section{PIPELINE CONCEPTIONAND IMPACT OF AMBIENT CONDITIONS}

Trajectory of the exemplary offshore pipeline for carbon dioxide transport is 76 kilometers long, in its lowermost section is situated 84 meters b. s. 1. The outlet point of the pipeline is disposed on the offshore platform, over the sea level. Scheme of offshore pipeline conception is shown in Fig. 6.

Ambient temperature has a high influence on the conditions of carbon dioxide pipeline transportation. In the summer, the surface layer of sea water (in moderate climate zone) heats up to about $20^{\circ} \mathrm{C}$ [13]. A thermocline (transient zone) is encountered at a depth of $20-30 \mathrm{~m}$ where shows significant drop of temperature to about $6-8^{\circ} \mathrm{C}$ [13]. The water temperature during the winter season in the coastal zone varies around $0^{\circ} \mathrm{C}$, and with the depth slightly increases to a maximum level of about $4^{\circ} \mathrm{C}$. Changes in ambient temperature as function pipeline length in summer and winter conditions are shown in Fig. 7.

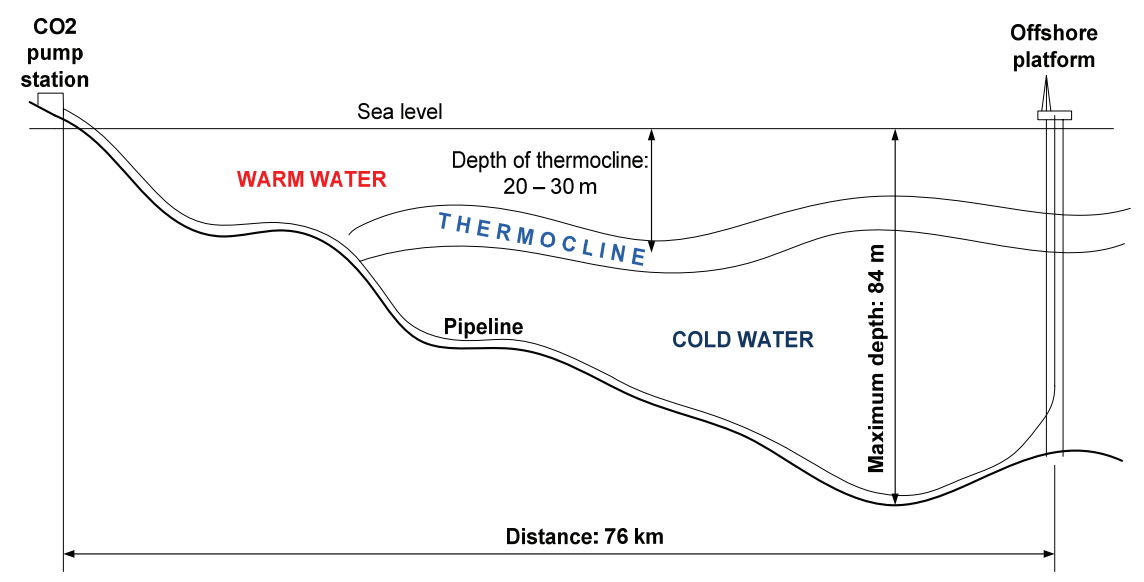

Fig. 6. Undersea offshore pipeline scheme

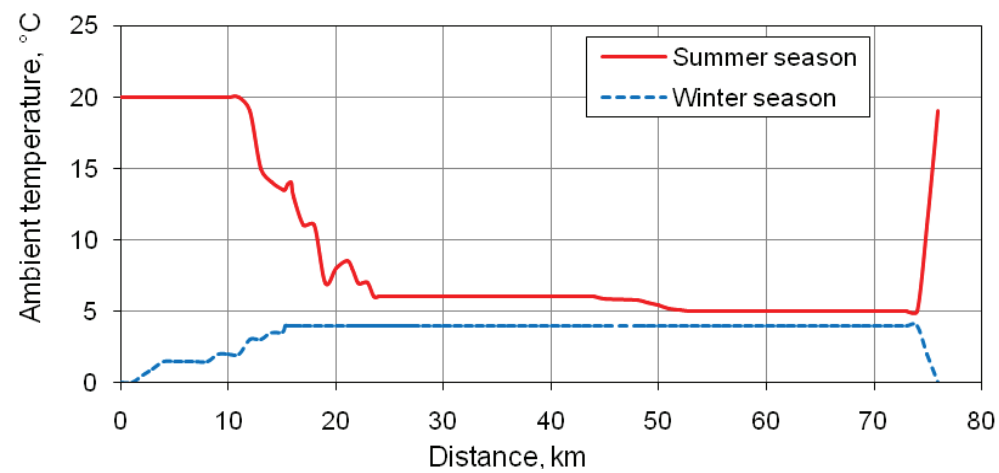

Fig. 7. Profile of ambient temperature along the proposed pipeline route, based on: [13] 


\section{THERMODYNAMIC ASSUMPTIONS}

The thermodynamic properties of carbon dioxide are different from other fluids transported by pipeline, i.e. natural gas [14]. Carbon dioxide may be transported conventionally in the gas phase or in the liquid phase and as supercritical fluid. Examples of properties of $\mathrm{CO}_{2}$ in each of these phases are shown in Table 2. $\mathrm{CO}_{2}$ transport in gas phase is inefficient because of the low density of the carbon dioxide and high pressure drop as a function of pipeline length $[14,15,16]$. Carbon dioxide in liquid phase or supercritical state must be transported at a high pressure range - in the case of a supercritical state also above the critical point parameters (Table 2). Supercritical state is the most effective for pipeline transport, however, maintaining high temperature of carbon dioxide above the critical temperature is highly energy-intensive. From a technical point of view, an effective way of $\mathrm{CO}_{2}$ transport is liquid phase transport. Liquid phase $\mathrm{CO}_{2}$ may be transported in a wide range of pressure and temperature (the analysis of the phase envelope of mixture $99 \% \mathrm{CO}_{2}$ and $1 \% \mathrm{~N}_{2}$ - Figure 8 ). Above the critical pressure liquid phase occurs in a wide range of temperatures up to the critical temperature. For the liquid phase it is possible to reduce the pipeline operating pressure at a lower temperature of transported carbon dioxide. In this case, the pipeline transport of $\mathrm{CO}_{2}$ has a higher energy efficiency, but it is necessary to control the temperature of transported $\mathrm{CO}_{2}$ and impact of ambient conditions. The increase of temperature can result in the emergence of a two-phase system and consequently, a rapid drop of pressure in the pipeline because of lower density and then transition to the gas phase.

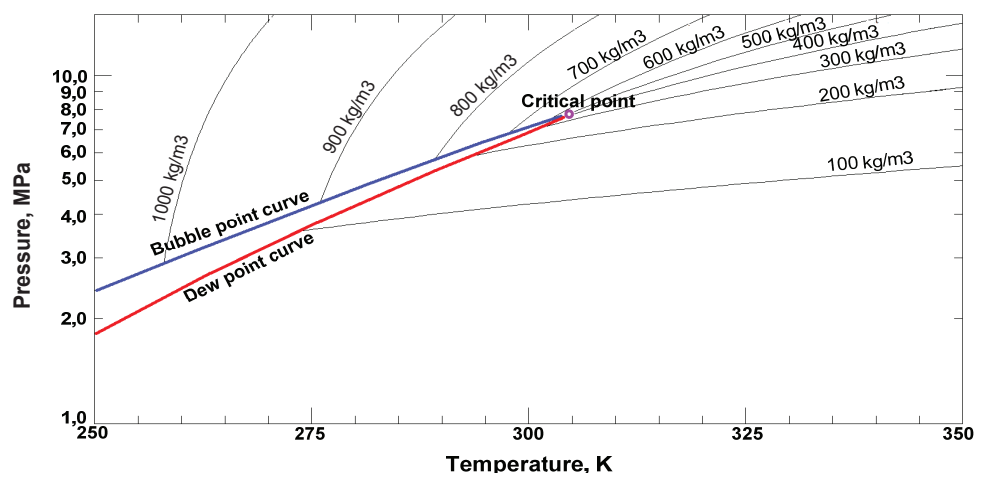

Fig. 8. Plot p-T (phase envelope) for a bi-component mixture of $\mathrm{CO}_{2}$ (mole percentage $99 \%$ ) and $\mathrm{N}_{2}$ (mole percentage $1 \%$ )

Table 2

Exemplary properties of $\mathrm{CO}_{2}$ in different phases for pipeline transport based on: [16]

\begin{tabular}{|c|c|c|c|c|c|}
\cline { 2 - 6 } \multicolumn{1}{c|}{} & Gaseous & $\begin{array}{c}\text { Liquid below critical } \\
\text { pressure }\end{array}$ & $\begin{array}{c}\text { Liquid above } \\
\text { critical pressure }\end{array}$ & Supercritical & $\begin{array}{c}\text { Critical } \\
\text { point }\end{array}$ \\
\hline Pressure, $\mathrm{MPa}$ & $3-4$ & Above 6 & Above 7.5 & Above 7.5 & 7.38 \\
\hline Temperature, ${ }^{\circ} \mathrm{C}$ & $10-15$ & Below 15 & Up to 30 & Above 35 & 31.1 \\
\hline Density, $\mathrm{kg} / \mathrm{m}^{3}$ & $70-100$ & $800-900$ & $700-1100$ & $300-800$ & 468 \\
\hline Viscosity, $\mu \mathrm{Pas}$ & $\sim 15$ & $\sim 70-80$ & $\sim 80-110$ & $\sim 25-60$ & $\sim 40$ \\
\hline
\end{tabular}




\section{SELECTION OF MATERIALS}

Bearing in mind the assembly mode and the unevenness of the seabed, a coiled-tubing pipeline has been proposed. For this solution, relatively small diameters of pipelines are used (maximum 6" outer diameter-OD) which creates optimum conditions for the assumed rates of $\mathrm{CO}_{2}$.

The coiled-tubing pipeline is laid on the seabed with the use of a drum method, i.e. the pipeline is unwrapped from a drum disposed on a floating vessel. In this way the operators can lower the investment costs, operational costs and the risk related to the project realization [17].

Covered pipes produced in the coiled-tubing technology can be $1500 \mathrm{~m}$ long for 5" OD and $7000 \mathrm{~m}$ long for $23 / 8$ " OD, which creates great construction possibilities for the undersea pipelines. In view of this, coiled-tubing pipelines are recommended for $\mathrm{CO}_{2}$ transport to a reservoir area with a mass flow rate up to $0.3 \mathrm{MtCO}_{2} /$ year. Simulations will be performed for this type of pipeline at the mass flow rate of $0.3 \mathrm{MtCO}_{2} /$ year.

The proposed coiled-tubing pipelines should comply with the standard API 5LC. They should be made of steel X52C or X65C for nominal outer diameters 3.5" to 5". In view of the expected operating pressure of the pipeline, the coiled-tubing pipelines of steel X52C with minimum thickness of pipeline walls were proposed for the calculations. The maximum admissible operating pressure for pipelines of given diameters are listed in table 3.

Table 3

Operating pressure and hydraulic test pressure for coiled-tubing pipelines (parameters assumed from the producer's catalog [18])

\begin{tabular}{|c|c|c|c|}
\hline $\begin{array}{c}\text { Outer diameter OD } \\
\text { inch / mm }\end{array}$ & $\begin{array}{c}\text { Inner diameter ID } \\
\text { inch / mm }\end{array}$ & $\begin{array}{c}\text { Maximum operating pressure } \\
\mathrm{psi} / \mathrm{MPa}\end{array}$ & $\begin{array}{c}\text { Hydraulic test pressure } \\
\mathrm{psi} / \mathrm{MPa}\end{array}$ \\
\hline $5 " / 127 \mathrm{~mm}$ & $4.5 " / 114.3 \mathrm{~mm}$ & $3600 \mathrm{psi} / 24.82 \mathrm{MPa}$ & $4500 \mathrm{psi} / 31.03 \mathrm{MPa}$ \\
\hline $4,5 " / 114.3 \mathrm{~mm}$ & $4 " / 103.9 \mathrm{~mm}$ & $3280 \mathrm{psi} / 22.16 \mathrm{MPa}$ & $4100 \mathrm{psi} / 28.27 \mathrm{MPa}$ \\
\hline $4 " / 101.6 \mathrm{~mm}$ & $3.55 " / 90.9 \mathrm{~mm}$ & $4000 \mathrm{psi} / 27.58 \mathrm{MPa}$ & $5000 \mathrm{psi} / 34.48 \mathrm{MPa}$ \\
\hline
\end{tabular}

\section{CALCULATIONAND SELECTION OF PIPELINE DIAMETER}

The basic problem encountered of pipeline designing process is to determine optimum diameter. Pipeline diameter may be calculated using following formula for average temperature conditions (isothermal flow) based on Bernoulii equation and Peng-Robinson equation of state $[19,20]$ :

$$
D=\left(\frac{16 \lambda z^{2} R^{2} T^{2} L M^{2}}{\pi^{2}\left[z R t\left(p_{2}^{2}-p_{1}^{2}\right)\right]-2 g p_{s r}^{2} \Delta h}\right)^{\frac{1}{5}}
$$

Where $\lambda$ is linear friction factor, $z$ is compressibility factor, $R$ is specific gas constant, $T$ is average temperature, $L$ - pipeline distance, $M$ - mass flow rate, $p_{1}$ - inlet pressure, $p_{2}-$ outlet pressure, $g$ - gravity constant, $p_{s r}$ - average pipeline pressure and $\Delta h$ is level difference. 
The basic assumptions for pipeline diameter selection have been found by simulation program. Two variants of mass flow rate were analyzed in the paper:

- $0.1 \mathrm{MtCO}_{2} /$ year

- $0.3 \mathrm{MtCO}_{2} /$ year - basic variant

Pressure at the pipeline output was determined in order to maintain the transported carbon dioxide in a liquid phase within the pressure and temperature range assumed for the pipeline operation:

- 6.0 $\mathrm{MPa}\left(\mathrm{T}_{\max }=15^{\circ} \mathrm{C}\right.$ - to maintain the liquid phase at a specified pressure $\left.6 \mathrm{MPa}\right)$;

- $7.0 \mathrm{MPa}\left(\mathrm{T}_{\max }=25^{\circ} \mathrm{C}\right.$ - to maintain the liquid phase at a specified pressure $\left.7 \mathrm{MPa}\right)$.

Length of pipeline - $76 \mathrm{~km}$;

Maximum change of ground level - $84 \mathrm{~m}$;

Calculated diameter as a result of equation (1) was compared with available diameters from producer's catalogue. Tables 4 and 5 provide data on the basis of which the pipeline diameter and the pipeline's operating pressure (determined with simulation software) required for the assumed diameter and mass flow rate values can be determined.

\section{Table 4}

Required input pressure for selected diameters depending on the mass flow rate and assumed outlet pressure of $6 \mathrm{MPa}$, according to the performed simulations

\begin{tabular}{|c|c|c|c|c|}
\hline \multicolumn{5}{|c|}{ Coiled tubing pipeline (steel X52C) } \\
\hline $\begin{array}{l}\text { Pressure at the } \\
\text { pipeline outlet } \\
{[\mathrm{MPa}]}\end{array}$ & $\begin{array}{l}\text { Outer diameter } \\
\text { OD inch } / \mathrm{mm}\end{array}$ & $\begin{array}{c}\text { Inner diameter ID } \\
\text { inch } / \mathrm{mm}\end{array}$ & $\begin{array}{l}\text { Mass flow rate } \\
{\left[\mathrm{MtCO}_{2} / \text { year }\right]}\end{array}$ & $\begin{array}{l}\text { Pressure at the pipeline } \\
\text { inlet in summer period } \\
{[\mathrm{MPa}]}\end{array}$ \\
\hline \multirow{2}{*}{$6.0 \mathrm{MPa}$} & \multirow{2}{*}{$5 " / 127 \mathrm{~mm}$} & \multirow{2}{*}{$4.5 " / 114.3 \mathrm{~mm}$} & 0.1 & 7.02 \\
\hline & & & 0.3 & 11.38 \\
\hline \multirow{2}{*}{$\left(\mathrm{T}_{\max }=15^{\circ} \mathrm{C}\right)$} & \multirow{2}{*}{$4.5 " / 114.3 \mathrm{~mm}$} & \multirow{2}{*}{ 4" / $103.9 \mathrm{~mm}$} & 0.1 & 7.43 \\
\hline & & & 0.3 & 14.44 \\
\hline & $4.0 " / 101.6 \mathrm{~mm}$ & $3.55 " / 90.9 \mathrm{~mm}$ & 0.1 & 8.32 \\
\hline
\end{tabular}

Table 5

Required inlet pressure for selected diameters depending on the mass flow rate and assumed outlet pressure of $7 \mathrm{MPa}$, according to the performed simulations

\begin{tabular}{|c|c|c|c|c|}
\hline \multicolumn{5}{|c|}{ Coiled tubing pipeline (steel X52C) } \\
\hline $\begin{array}{c}\text { Pressure at the } \\
\text { pipeline outlet } \\
{[\mathrm{MPa}]}\end{array}$ & $\begin{array}{c}\text { Outer diameter } \\
\text { OD inch / } \mathrm{mm}\end{array}$ & $\begin{array}{c}\text { Inner diameter ID } \\
\text { inch / mm }\end{array}$ & $\begin{array}{c}\text { Mass flow rate } \\
{\left[\mathrm{MtCO}_{2} / \text { year }\right]}\end{array}$ & $\begin{array}{c}\text { Pressure at the pipeline } \\
\text { inlet in summer period } \\
{[\mathrm{MPa}]}\end{array}$ \\
\hline \multirow{2}{*}{$7.0 \mathrm{MPa}$} & $5 " / 127 \mathrm{~mm}$ & $4.5 " / 114.3 \mathrm{~mm}$ & $\mathbf{0 . 1}$ & $\mathbf{7 . 9 3}$ \\
\cline { 4 - 6 }$\left(\mathrm{T}_{\max }=25^{\circ} \mathrm{C}\right)$ & $4.5 " / 114.3 \mathrm{~mm}$ & $4 " / 103.9 \mathrm{~mm}$ & $\mathbf{0 . 1}$ & $\mathbf{1 2 . 3 0}$ \\
\cline { 4 - 6 } & $4.0 " / 101.6 \mathrm{~mm}$ & $3.55^{\prime} / 90.9 \mathrm{~mm}$ & $\mathbf{0 . 3}$ & $\mathbf{0 . 2 5}$ \\
\hline & & & & $\mathbf{1 5 . 3 5}$ \\
\hline
\end{tabular}


Figure 9. presents agraphical dependence of the required inletpressurevs. pipeline diameter for a few mass flow rate values.

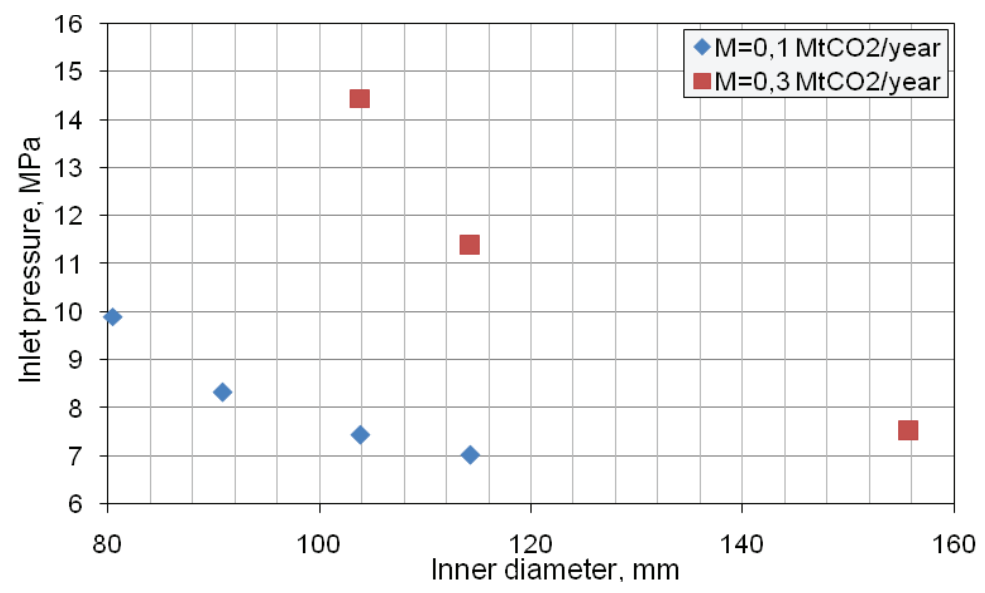

Fig. 9. Required pressure at the pipeline inlet vs. inner diameter of pipeline for the outlet pressure of $6 \mathrm{MPa}$

\section{CONCEPT OF TECHNOLOGICALSYSTEMS}

Pipelines designed for $\mathrm{CO}_{2}$ transport should be equipped with suitable technological systems for both: transport at a high pressure and also at the stage of preparation to the transport. This should ensure efficient and safe transport of $\mathrm{CO}_{2}$.

Two variants of $\mathrm{CO}_{2}$ pipeline transport are possible:

In the first variant the $\mathrm{CO}_{2}$ preparation station, compression station and pumping stations are installed on land. Then carbon dioxide is pumped towards the reservoir area at such an input pressure, that the required wellhead pressure is obtained at the pipeline outlet and $\mathrm{CO}_{2}$ can be injected to the geologic structure of the reservoir (Fig. 10).

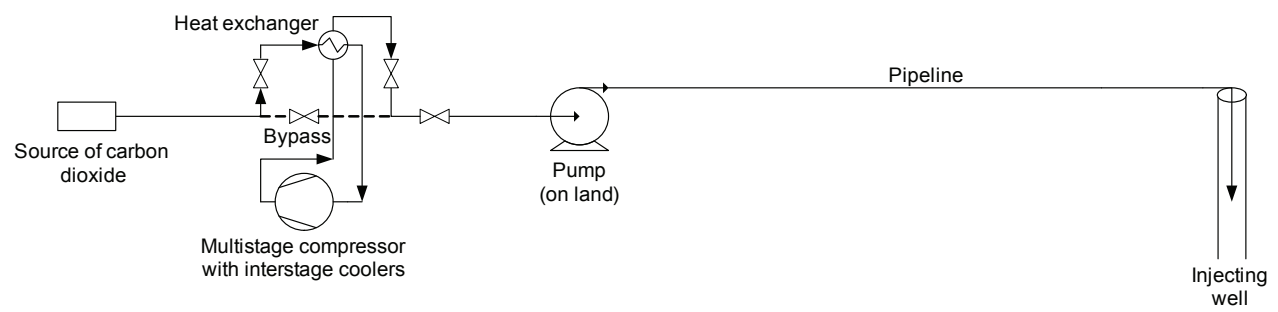

Fig. 10. $\mathrm{CO}_{2}$ transport scheme - increase of pumping pressure to a value at which the pipeline transport from one place to the injection site and then injection of carbon dioxide to the wellbore is possible 
In the second variant, apart from installations mentioned above, additional $\mathrm{CO}_{2}$ pumping stations are proposed on the offshore platform within the area of the reservoir (Fig. 11). This should allow for the regulation of pipeline inlet pressure, which shall no longer depend on the required wellhead pressure. The $\mathrm{CO}_{2}$ could be injected with the use of a pump installed on the platform. Apart from this, the operators could select the injection parameters directly on the platform.

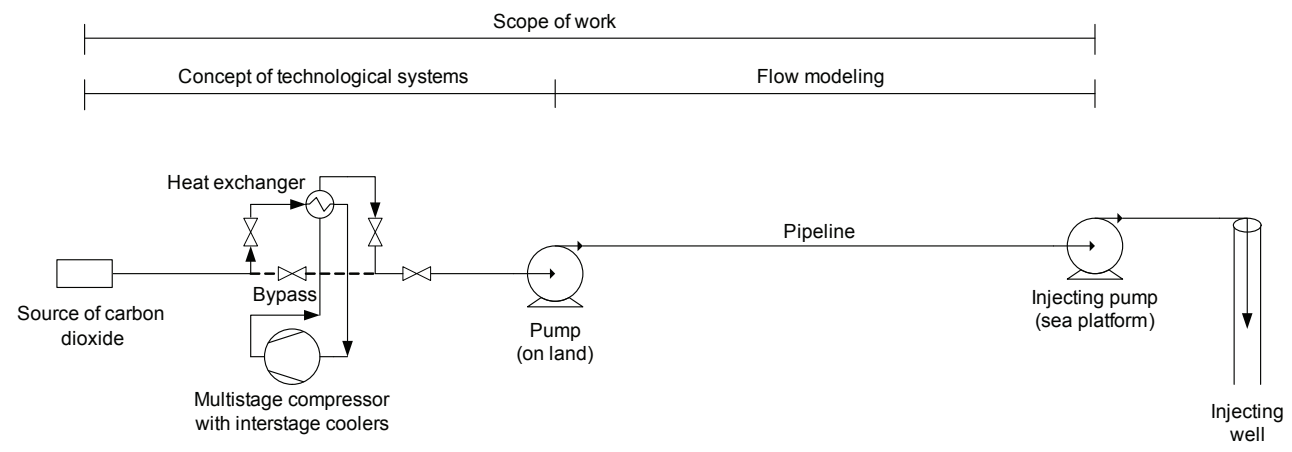

Fig. 11. $\mathrm{CO}_{2}$ transport scheme - installation of pumps transporting $\mathrm{CO}_{2}$ to a geological structure on a offshore platform

The second variant has many technological advantages, though the investment costs may be increased by the cost of installation of additional injection pumps. The minimum outlet pressure before the $\mathrm{CO}_{2}$ injection pump was assumed to be of $6 \mathrm{MPa}$ (at maximum temperature $15 \operatorname{deg} \mathrm{C}$ ) to maintain $\mathrm{CO}_{2}$ in liquid phase.

The basic technological systems accompanying $\mathrm{CO}_{2}$ transport are:

- station where $\mathrm{CO}_{2}$ is prepared for transport;

- $\mathrm{CO}_{2}$ compression and pumping station;

- heat exchanger station.

The shut-off and relief systems will not be used in the offshore conditions; the shut-off fixtures should be used at the onshore section, before the undersea one begins. In the offshore conditions no diagnostic pig launchers and catchers will be applicable either. The inability to inspect the coiled-tubing pipeline and the classic pipeline makes it necessary to thoroughly clean and dry $\mathrm{CO}_{2}$ prior to transporting it through the pipeline.

\section{CARBON DIOXIDE COMPRESSIONAND INTERSTAGE DRYING}

When carbon dioxide is continuously delivered in a gaseous form and we want to fit in the proposed transport conditions, $\mathrm{CO}_{2}$ should be compressed in multistage compressors with interstage cooling in heat exchangers, and reduced to the liquid state. Therefore, multistage piston compressors with electrical drive are proposed. Pumping systems which increase the $\mathrm{CO}_{2}$ pressure to the assumed value should be used for transporting carbon dioxide to the platform within an exemplary reservoir area. 
Carbon dioxide can be efficiently cleaned of water traces by interstage drying during multistage compression. Compression and interstage drying of $\mathrm{CO}_{2}$ were simulated for the basic variant. The results are available in table 6 .

The last stage of compression is followed by cooling of $\mathrm{CO}_{2}$ to a temperature of $5^{\circ} \mathrm{C}$ as a consequence of which the gas obtains a liquid phase.

Table 6

Simulation of $\mathrm{CO}_{2}$ compression in a 6-grade compressor with a demo software. Own study

\begin{tabular}{|l|l|c|c|c|c|c|c|}
\hline Compression stage & & $\mathbf{1}$ & $\mathbf{2}$ & $\mathbf{3}$ & $\mathbf{4}$ & $\mathbf{5}$ & $\mathbf{6}$ \\
\hline Mass flow rate & $\mathrm{Mt} / \mathrm{year}$ & 0.3 & 0.3 & 0.3 & 0.3 & 0.3 & 0.3 \\
\hline $\mathrm{CO}_{2}$ content & $\%$ & 98.5 & 98.5 & 98.58 & 98.77 & 98.87 & $\mathbf{9 8 . 9 1}$ \\
\hline $\mathrm{N}_{2}$ content & $\%$ & 1.0 & 1.0 & 1.0 & 1.0 & 1.0 & $\mathbf{1 . 0}$ \\
\hline $\mathrm{H}_{2} \mathrm{O}$ content & $\%$ & 0.5 & 0.5 & 0.42 & 0.23 & 0.13 & $\mathbf{0 . 0 9}$ \\
\hline Pressure at the inlet & $\mathrm{MPa}$ & $\mathbf{0 . 1}$ & $\mathbf{0 . 2}$ & $\mathbf{0 . 4 1}$ & $\mathbf{0 . 8 1}$ & $\mathbf{1 . 6 8}$ & $\mathbf{3 . 4 1}$ \\
\hline Pressure at the outlet & $\mathrm{MPa}$ & $\mathbf{0 . 2 1}$ & $\mathbf{0 . 4 2}$ & $\mathbf{0 . 8 5}$ & $\mathbf{1 . 7 2}$ & $\mathbf{3 . 4 8}$ & $\mathbf{7 . 0 7}$ \\
\hline Input temperature & ${ }^{\circ} \mathrm{C}$ & $\mathbf{2 0}$ & $\mathbf{1 5}$ & $\mathbf{1 5}$ & $\mathbf{1 5}$ & $\mathbf{1 5}$ & $\mathbf{1 5}$ \\
\hline Output temperature & ${ }^{\circ} \mathrm{C}$ & $\mathbf{7 0 . 8}$ & $\mathbf{6 6 . 8}$ & $\mathbf{6 7 . 4}$ & $\mathbf{6 8 . 5}$ & $\mathbf{7 1 . 0}$ & $\mathbf{7 5 . 2}$ \\
\hline \multicolumn{7}{|c|}{ Steam directed to interdrying } \\
\\
\hline $\mathrm{Mass}^{*}$ flow rate & $\mathrm{kg} / \mathrm{h}$ & - & - & 10.6 & 28.4 & 13.6 & 5.1 \\
\hline $\mathrm{CO}_{2}$ content & $\%$ & - & - & $\mathbf{0 . 3}$ & $\mathbf{0 . 6}$ & $\mathbf{1 . 2}$ & $\mathbf{2 . 4}$ \\
\hline $\mathrm{H}_{2} \mathrm{O}$ content & $\%$ & - & $\mathbf{9 9 . 7}$ & $\mathbf{9 9 . 4}$ & $\mathbf{9 8 . 8}$ & $\mathbf{9 7 . 6}$ \\
\hline
\end{tabular}

*- after compression the $\mathrm{CO}_{2}$ stream should be cooled down and liquefied

\section{PRESSURE AND TEMPERATURE CHANGES IN THE PIPELINE}

The carbon dioxide pipeline transport from the land to an offshore platform was simulated with dedicated computer software based on numerical calculations for the assumed pipeline trajectory. The simulations cover pressure and temperature profile for the outer diameter 4.5" and 5" (coiled-tubing) and mass flow rates (0.1 $\mathrm{MtCO}_{2} /$ year and $0.3 \mathrm{MtCO}_{2}$ /year - basic variant). Pressure profiles as a function of pipeline length for the selected pipe diameters 4.5 "and 5" and two mass flow rate variants are shown in Figure 12.

Due to the high variability of seawater temperatures in the surface zone (to about 20 $\mathrm{m}$ of depth) in a moderate climate zone, the temperature changes of transported $\mathrm{CO}_{2}$ were simulated for summer season conditions. Presented in figure 13 simulations were made for a pipeline outlet pressure $6 \mathrm{MPa}$, pipeline outlet diameter of 5 " and mass flow rate $0.3 \mathrm{Mt} /$ yr for three variants: pipeline located on seabed, coated under the seabed and thermally insulated. 


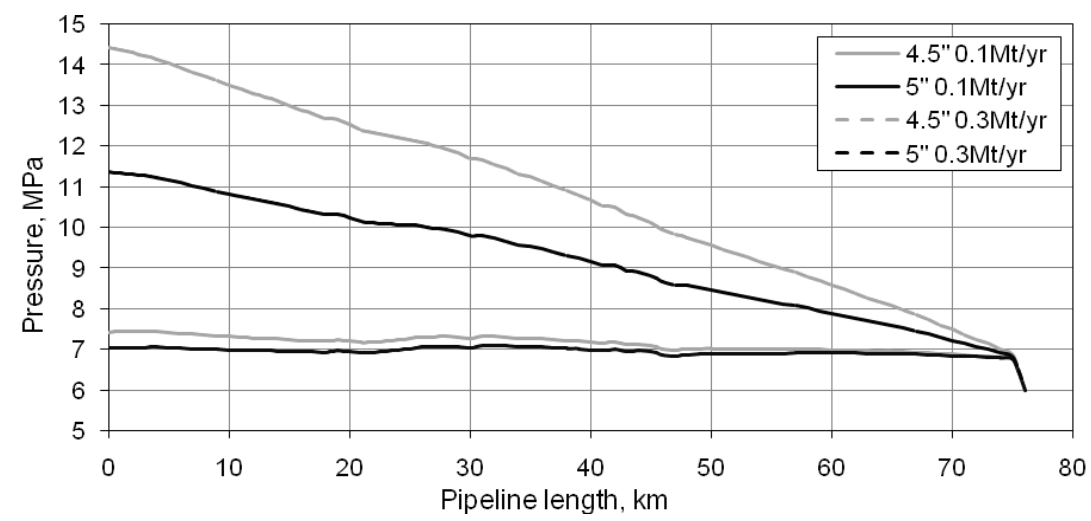

Fig. 12. Profile of pressure changes in a coiled-tubing pipeline with 4.5 " and 5" outer diameter and assumed outlet pressure of $6 \mathrm{MPa}$ for two variants of mass flow rate

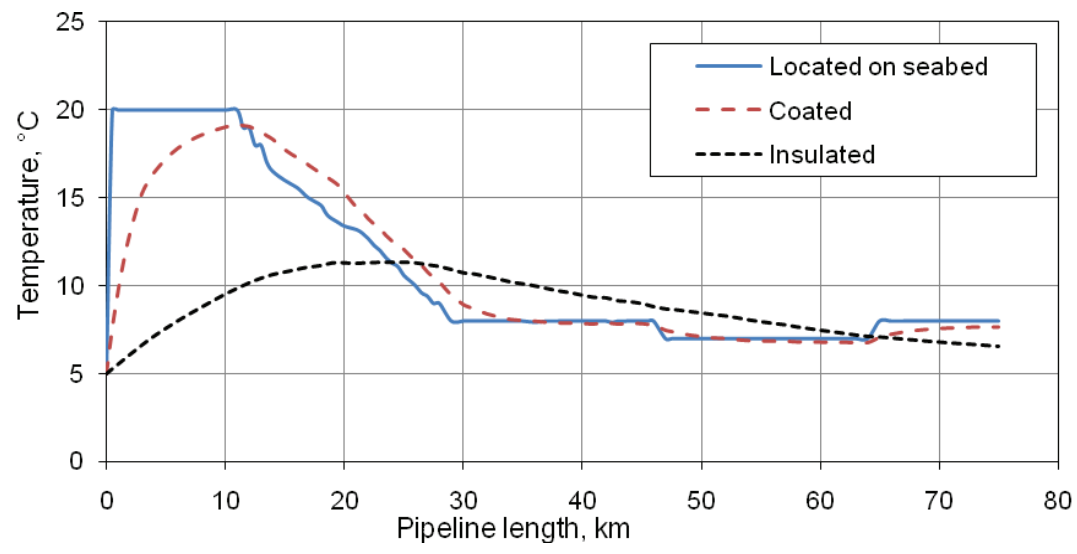

Fig. 13. Simulation of temperature changes in a coiled-tubing pipeline of 5 " outer diameter at a mass flow rate of $0.3 \mathrm{MtCO}_{2} /$ year in summer season

The simulations of temperature changes confirmed that the liquid phase can be maintained at lower outlet pipeline pressure (min. $6 \mathrm{MPa}$ ) due to the temperatures on the seabed. The use of thermal insulation should be considered in coastal zone where the influence of ambient temperature is relatively high especially in summer season.

\section{SUMMARY}

The basic thermodynamic, technical and economic conditions in which carbon dioxide will be transported by offshore pipeline are presented in this paper.

In the preferred variant, $\mathrm{CO}_{2}$ is to be transported in a liquid phase through a pipeline. A few pipeline diameter options were considered to determine the pipeline operating pressure 
for two maximum mass flow rate values. The analysis of the assumed variants reveals that carbon dioxide can be transported undersea with coiled-tubing pipelines at a distance of about $80 \mathrm{~km}$.

The way in which materials for the pipeline construction are selected has been analyzed. The coiled-tubing pipeline is recommended for a mass flow rate up to $0.3 \mathrm{MtCO}_{2} /$ year, and the classic steel pipeline (owing to the required larger diameter) for $0.6-0.9 \mathrm{MtCO}_{2} / \mathrm{year}$, respectively.

A few variants of pipeline diameter are proposed, depending on the mass flow rate value. For the basic variant $\left(0.3 \mathrm{MtCO}_{2}\right.$ /year $)$ the proposed pipeline option is coiled-tubing pipe with outer diameter $5 "$. Coiled-tubing pipeline can reduce investments costs.

For the basic variant the inlet pipeline (5" OD) pressure should be equal to: $11.38 \mathrm{MPa}$ for outer diameter of $5 \mathrm{inch}$ and 14.4 MPa for outer diameter of $4.5 \mathrm{inch}$, respectively, so that carbon dioxide in a liquid phase is transported. The simulations of temperature changes and the analysis of the results confirmed that the liquid phase can be maintained at lower outlet pipeline pressure (min. $6 \mathrm{MPa}$ ) due to the temperatures on the seabed. The use of thermal insulation can be recommended to minimize the influence of ambient temperature amplitudes in the coastal zone, onshore section and the surface zone at the platform.

Costs of offshore pipeline transportation are relatively higher than onshore pipeline. For long distances the transport of $\mathrm{CO}_{2}$ by ships might be considered.

Results presented in this paper were obtained in research cofounded by The National Centre for Research and Development in accordance to the agreement SP/E/1/67484/10. We gratefully acknowledge this support, as well as the encouragement of the program managers.

\section{REFERENCES}

[1] IPCC, 2005. Intergovernmental Panel on Climate Change. IPCC Special Report on Carbon Dioxide Capture and Storage. Prepared by Working Group III of the Intergovernmental Panel on Climate Change. Cambridge University Press, Cambridge, United Kingdom and New York, NY, USA

[2] ZEP. Zero Emissions Platform., 2011. The Costs of $\mathrm{CO}_{2}$ Capture, Transport and Storage. Post-demonstration CCS in the EU. European Technology Platform for Zero Emission Fossil Fuel Power Plants.

[3] Welkenhuysen K., Compernolle T., 2013. Economisc of single chain EOR projects. Port of Antwerp. EOR Seminar. June, 18, 2013.

[4] IEA GHG, 2002. International Energy Agency. Transmission of $\mathrm{CO}_{2}$ and Energy, IEA Greenhouse Gas R\&D Programme. Report PH4/6. IEA GHG, Cheltenham, UK (March).

[5] Bock B.R., Rhudy R., Herzog H., Klett M., Davison J., de la Torre Ugarte D.G., Simbeck D., 2003. Economic Evaluation of $\mathrm{CO}_{2}$ Storage and Sink Enhancement Options. TVA Public Power Institute, February 2003. 
[6] Chandler, H.M. 2000. Heavy Construction Cost Data - 14th Annual Editions. R.S. Means Company, Inc. Kingston, MA, USA.

[7] Hendriks, C.A., Wildenborg T., Feron P., Graus W., 2005. Capture and Storage, prepared for EC, DG-ENV, Ecofys Energy and Environment, report nr. M70066.

[8] O\&GJ, 2000. Pipeline Economics. Oil and Gas Journal, 98 (36), pp. 68-86.

[9] Ormerod B., 1994. The disposal of carbon dioxide from fossil fuel fired power stations. IEA Greenhouse Gas R\&D Programme, Cheltenham, Technical Rep. IEAGHG/SR3, June 1994.

[10] Sarv, H., 2001a, Further Technological Evaluation of CO2 Storage in Deep Oceans. Presented at the $26^{\text {th }}$ International Technical Conference on Coal Utilisation \& Fuel Systems, March 5-8, 2001, Clearwater, Florida.

[11] Sarv, H., 2001b, Large-scale CO2 transportation and deep ocean sequestration - Phase II final report. McDermott Technology Inc., Ohio. Technology Report DEAC26-98FT40412, 2001.

[12] Sarv, H., John J., 2000, Deep ocean sequestration of captured CO2. Technology, 7S, $125-135$.

[13] Urbański J., Szymelfenig M., Morze Battyckie - o tym warto wiedzieć. [w:] Zeszyty Zielonej Akademii, 2008, Zeszyt 7

[14] McCoy S. T., The Economics of $\mathrm{CO}_{2}$ Transport by Pipeline and Storage in Saline Aquifers and Oil Reservoirs, PhD, Pittsburgh, PA 2008.

[15] McCoy S. T., Rubin S. An engineering-economic model of pipeline transport of ${ }_{\mathrm{CO} 2}$ with application to carbon capture and storage. International Journal of Greenhouse Gas Control Vol. 2 (2008) 219 - 229.

[16] Zhang Z.X., Wang G.X., Massarotto P., Rudolph V.: Optimization of Pipeline Transport for $\mathrm{CO}_{2}$ Sequestration. Elsevier Energy Conversion and Management 47 (2006).

[17] Magda W., Rurociagi podmorskie Zasady projektowania, Warszawa 2004.

[18] Coiled-tubing pipes catalogue / Katalog rur typu coiled-tubing - TENARIS CO.

[19] Rybicki C., Łaciak M., Transport rurociagowy $\mathrm{CO}_{2}$. [w:] Rurociągi, nr 4, 2008.

[20] Włodek T.: Wybrane aspekty techniczne rurociagowego transportu dwutlenku węla. [w:] AGH Drilling-Oil-Gas Quaterly Vol. 29 No. 1, 2012

[21] Murray A., Mohitpour M., Golshan H., Pipeline Design and Construction. A practical approach. ASME PRESS 2003.

[22] REFPROP NIST 9.0 